\title{
MOTIVATORS TO RECOMMEND SOCIAL NETWORK CONTACTS TO EMPLOYER
}

\author{
TOM SANDER ${ }^{1}$, BIRUTA SLOKA ${ }^{2}$ \\ University of Ludwigshafen (Geramany), University of Latvia (Latvia)
}

\begin{abstract}
Social networks are an important tool for human resources management to identify employees. The number of suitable candidates to fill a position is decreasing. Companies need new channels for the recruiting process. This paper evaluates the usefulness of the different social networks under consideration of the advantages and disadvantages. "Employee recruit Employees" is a useful tool to identify suitable candidates. The aim of the paper is to analyse the different motivators and reasons of individuals to recommend somebody to identify employer. The research methods are: theoretical studies of published scientific findings and survey with 251 respondents. The data obtained in the survey were analysed with indicators of central tendency or location: arithmetic mean, median or mode and t-test to compare the gender differences.

KEY WORDS: social network, social capital, employee recruit employees, human resources management.
\end{abstract}

JEL CODES: L14; E24; O15.

\section{Introduction}

The difficulties to identify suitable candidates for employment are increasing. Many companies need new qualified employees. The demographic chances and skills shortage makes it very difficult to recruit needed employees (Sarabia, Estévez, 2016: 224). The companies have disadvantages with the gap and missing skilled employees. This is a critical issue for the economy.

"Employee recruits Employees" is a popular tool to use employees as a recruiter. They are using their social networks to identify suitable candidates and recommend the candidates to their company (Han, Han, 2009: 2241; McDonald, 2011: 318). Companies motivate their employees with motivators to recommend somebody e.g. financial bonus or something else. The employees use their social network for their company. Social networks for example family, friends etc. (Granovetter, 1995: 104). The influence of motivators on the use of social networks for "employee recruits employees" is under observation. The importance of motivators influences the recommendations and kind of social networks for employee recruits employees.

The reason to use social networks of the employees to recruit new employees is that the companies do not find on traditional paths employees. The company expect to get access to potential candidates. That the employees use their relationships to influence their friends positive to apply (Potkany, Hajdukova, 2015: 78). The employees are doing a pre-screening. That can increase the quality of candidates. The company can

1 Tom Sander - doctoral student at University of Ludwigshafen (Germany)

Scientific interests: social networks for HRM

E-mail: tomsander@hotmail.de

Tel. + 4916098753917

2 Biruta Sloka - professor at University of Latvia, Faculty of Economics and Management, Latvia

Scientific interests: marketing research and social networks

E-mail: Biruta.Sloka@lu.lv

Tel. + 37129244966 
safe costs because their efforts are less to identify suitable candidates. The company use the knowledge of the employees about their friends. Employees are an important asset of companies. They are important for the success of companies and a critical unique resource in some industries (Racz, 2000: 43; Philips, Gully, 2015: 1426). The employees are the difference between companies. The recruiting process is important for the success of companies and needs new channels to be competitive on the labour market.

The goal of the paper is to analyse the different motivators and reasons of individuals to recommend somebody to identify employer. The research methods used in the current research are: theoretical studies of published scientific findings and survey to identify usefulness of the different social networks for employment seeking process and check the differences by gender of those findings. 251 respondents were included in the survey. The data obtained in the survey were analysed with indicators of central tendency or location: arithmetic mean, median or mode and t-test to compare the gender differences for the responses.

The paper recommend at the end the best suitable social network for "employee recruit employees" and most suitable motivators to make the employee recruit employees tool attractive for employees. The advantages and disadvantages are analysed. Those are arguments for or against "employee recruits employees" projects. The success to hire interesting candidates can be increased with the selection of the best motivator. That would support organisations.

\section{Theoretical Background}

Social networks are relationships between individuals. Social networks have different tasks and purpose for the individuals. The social networks are an important part of the society. Individuals exchange information and resources in their networks. They share their knowledge and make investments in the network. They expect for their investments a valuable return. The network operates because individuals trust each other. The social network has norms and culture which support the transfer of information and resources. That reduces the transaction costs and provides a fast and easy access to needed resources (McDonald, et al, 2009: 389). The reason to join a network is a benefit for the individuals.

The social capital theory is a prominent social network theory. The theory explains mechanism and operations in social networks with trust, obligations and advantages. The transfer of information and resources in social network depends on the expected benefit for the social network members (Borgatti, Ofen, 2010: 26; Chang, et al, 2015: 231; Roberts, Sambrook, 2014: 579; Sauer, Kauffeld, 2013: 39). They would not exchange their resources if they would not have a benefit. The individuals in social networks are equal because they have the same background, interest or objective. The social network members have similar background, experience and history. Some people describe the social network with the neighbourhood or community because people know each other absconding (Helliwell, Putnam, 1999: 261). They have similar living conditions and mainly the same culture. The structure of social networks is important for the mechanism and operations of social networks. The dense of social networks influence the level of trust and exchange of information for example (Granovetter, 1973: 1368; Baker-Doyle, 2015: 78; Mayer, 2012: 1273; Houghton, Joinson, 2010: 92). The investment in networks and benefits depend on a relevant level on the dense of the relationship. That leads to the assumption that dense networks are more often used to recruit employees. The expectation is that for example the family as a social network is the mainly used social network for employee recruits employees.

A second factor which influences the readiness to recommend somebody is the motivator. The expectation is that motivators have a positive influence on the behaviour, that individuals are motivated to recommend somebody to their employer. That employer has the chance to influence the individuals to recommend somebody. The motivator supports the decision process of the individual. That can lead the individual to a desired behaviour.

Social networks can have negative or positive results for the society. The positive economical outcome is the quick and easy access to needed resources. The negative outcome is the exclusion of individuals. The opportunity to oversee beneficial resources is given and has to be under consideration (Gray, et al, 2007: 
153). The social capital theory knows the negative outcome of social networks for example that innovations are reduced if teams are too dense (Portes, 2000: 11). That reduces the knowledge and innovation power of social networks. The other danger is corruption and partisanship. That means the decision is influenced by none relevant facts e.g. the relationship between individuals. The relationship may not be an argument to employ somebody or not. The negative outcomes can be a reason not to use social networks as a recruiting tool.

The gender difference in social networks is under observation (McDonald, et al, 2009: 394; Sorokowski, et al, 2016: 371). The research analyse the influence of the gender on the behaviour in social networks.

\section{Research methods for empirical research}

The research has been done in cooperation with a project at university of Ludwigshafen. The data has been collected with an online survey in April 2016. The questions are part of a survey about employment seeking relevant topics. The questionnaire was designed based on theoretical findings about the social network use for employment seeking process indicating several aspects on the motivation to recommend somebody for employer. The analysed aspects were asked to respondents to evaluate in the scale 1-6, the scale corresponds with the German grading system in schools. There are 251 respondents. The gender distribution among the respondents is $30.13 \%$ men and $69.87 \%$ women. The majority of the participants is between 26 and 30 years. Share of respondents under 30 years are $67.95 \%$. The details of the age distribution are presented in the figure one. Important aspect for the research is that only $12.55 \%$ of the respondents are over 40 years. The age distribution is for the employment seeking process relevant because too young or old people are not looking for work or do not work at the moment. The education level provides the information that $75.33 \%$ have minimum an apprenticeship degree. People in Germany need an apprenticeship or higher degree to be qualified for a regular qualified position. The research is investigating the recruitment of qualified employees. The qualification of employees is important that the employees can fulfil their tasks successfully. That provides a competitive advantage to organisations (Lado, Wilson, 2015: 714). They are of interest for the labour market and have skills which are of interest for the employer. The details of the education distribution are presented in figure one. The research is concentrating on Germany and all respondents speak German.

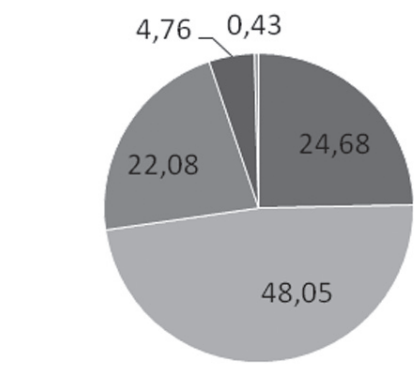

school degree

apprenticeship

university degree (three years duration e.g. Bachelor)

Univesity degree (more than three years e.g. Master)

Phd, doctorate or higher university degree

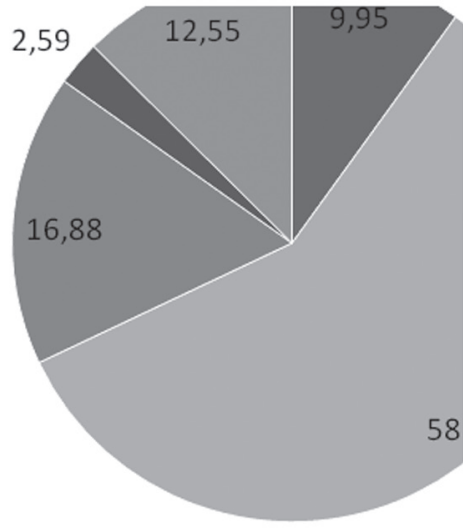

$$
\begin{array}{ll}
\square \text { up to } 25 & \square 26-30 \\
\square 31-35 & \square 36-40
\end{array}
$$

more than 40

Figure 1. Distribution Respondents by Education and Age (in \%)

Source: Tom Sander conducted survey in 2016, $n=251$ 
The data has been analysed with indicators of central tendency or location and t-test to provide an answer on the research question. The Cronbach alpha is 0,972 . That is a good value for the reliability. The scale is from one for full agreement to six for full disagreement to evaluate the statements. The applied evaluation scale corresponds to school grading system used in Germany.

\section{Results}

The results provide an overview about reasons who would be recommended and why would be somebody recommended or not recommended. The access to different networks is of interest for companies to transfer information to potential candidates. There are many networks and the paper concentrates on different social networks. The family as a very strong and dense network, with a clear structure and hierarchy, long history and high level of trust has the median two but the mode three. That means there is a clear tendency that family member would be recommended. A more positive result has the best friend and former colleague with median and mode of two.

Table 1. Social network which would be used to recommend somebody to an employer

\begin{tabular}{|c|l|l|l|l|l|}
\hline & Family & Best friend & $\begin{array}{c}\text { Acquaintance e.g. } \\
\text { neighbour }\end{array}$ & $\begin{array}{c}\text { Former } \\
\text { colleagues }\end{array}$ & \multicolumn{1}{c|}{$\begin{array}{c}\text { The only reason to recommend } \\
\text { somebody is the bonus }\end{array}$} \\
\hline Mean & 2 & 1,84 & 2.42 & 2.04 & 4.19 \\
\hline Median & 2 & 2 & 3 & 2 & 6 \\
\hline Mode & 3 & 2 & 3 & 2 & 6 \\
\hline
\end{tabular}

Source: Tom Sander conducted survey in 2016, $n=243$; Evaluation scale 1 - full agreement; 6 - full disagreement

That means the best friend and former colleague have a more positive result than the family. The chance that somebody recommends a family member to the employer is less assumable than the best friend or a former colleague. The second last place have acquaintance e.g. neighbours with median and mode of three. The recommendation depends on the network and material related motivators e.g. bonus is not the only reason. The importance of the network is tested with the question if only the bonus would be responsible that somebody recommend a new employee. The result is clear. Median and mode is six for the statement "the only reason to recommend somebody is the bonus". The participants differentiate between the networks and the usefulness of the networks to identify suitable candidates. Comparing the different social networks provides the feedback that the respondents have clear preferences.

The tendencies and results of the mode and median are supported by the mean results. The suitability of the social networks is different in the opinion of the respondents. The relevance of the bonus is related with the origin of the potential candidate. The details of the responses on question "Please imagine, your company offers an interesting bonus to recommend new employees, whom would you recommend?" is presented in Figure 2. The diagram two provides a clear tendency to one except the statement "the only reason to recommend somebody is the bonus. The recommendation does not only depend on the bonus.

Figure 2 illustrates that the majority of the responses is distributed on the first three stages except the statement "the only reason to recommend somebody is the bonus". That means the kind of social network is important but any social network is accepted with some small differences. That means individuals would provide their employer access to their social networks to identify successfully new employees.

The next results provide the motivation to recommend somebody. The results above present that the social network is important that individuals recommend somebody. The motivation can be increased with a benefit from the company for recommendations. That support the recommendation process and to use the tool "employee recruit employees". 


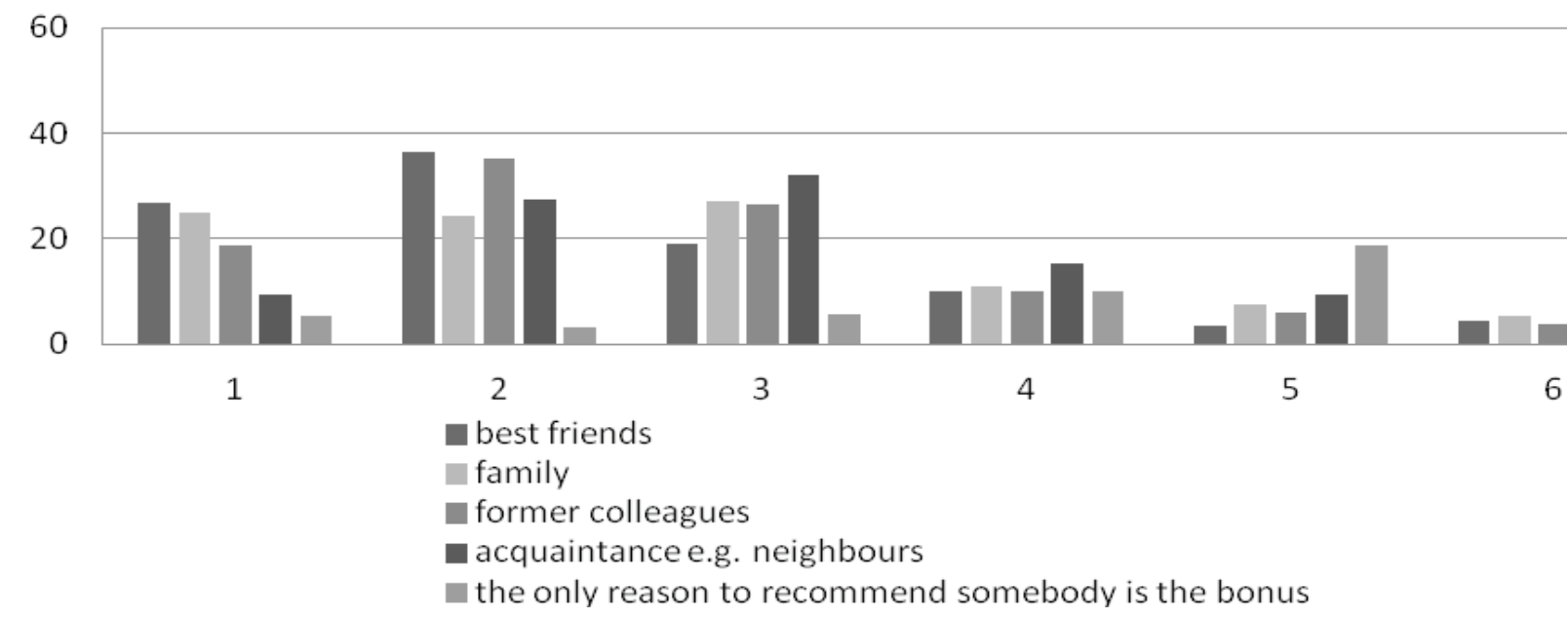

Figure 2. Distribution of responses on question "Please imagine, your company offers an interesting bonus to recommend new employees. Who would you recommend?" (in \%)

Source: Tom Sander conducted survey in 2016, $n=241$; Evaluation scale 1 - full agreement; 6 - full disagreement

Table 2. Main statistical indicators of central tendency on motivational factors to recommend a potential candidate to a company

\begin{tabular}{|c|c|c|c|c|c|}
\hline & Gift & $\begin{array}{c}\text { Opportunity of possible } \\
\text { promotion }\end{array}$ & $\begin{array}{c}\text { To receive more } \\
\text { holidays }\end{array}$ & $\begin{array}{c}\text { Increasing my } \\
\text { reputation }\end{array}$ & Money Bonus \\
\hline $\mathrm{n}$ & 251 & 251 & 251 & 238 & 251 \\
\hline Mean & 2,73 & 1,68 & 1,69 & 2,86 & 1,87 \\
\hline Median & 3 & 2 & 2 & 3 & 2 \\
\hline Mode & 3 & 1 & 1 & 3 & 2 \\
\hline
\end{tabular}

Source: Tom Sander conducted survey in 2016, $n=241$; Evaluation scale 1 - full agreement; 6 - full disagreement

The most positive motivation is the opportunity to receive additional holidays and the opportunity to be promoted for a higher career level. Both statements are evaluated with the mode one and median two. On the third place is receiving money. The money bonus has the mode and median two. The gift is a material bonus. The gift and the chance that the reputation would be increased has the median and mode three. That means the no one of the aspects of material motivation to increase the reputation is on the last place. The money motivation is on the third place. The assumption is that individuals would not "sell" their friend to the company for money or material bonuses. They are more interested in holidays and promotion to improve their career. The results are confirmed in the diagram three and the mean support the results. The results concentrate on the first three stages of the evaluation scale.

The advantages and disadvantages to recommend somebody to the current employer are different. Individuals are aware that they could have disadvantages and that can influence their decision to recommend somebody to their company. The largest anticipated danger is that employees feel responsible for the recommended employee. That means if the recommended employee fails than they would be responsible. The negative result would be related to them and their skills. The mode is on the stage one and the median is two. This provides a clear tendency. The second largest issue is that individuals do not like to mix their private and business life. The respondents answered that business and private life should be separated. The median is three and the mode is two for this statement. They like to protect their private life but the tendency is not so strong as the feeling of responsibility. That the new employee would dispute their position or that there will be a competition between the recommended employee and the person who suggest the candidate is not expected. The result is four for the median and three for the mode. The mean support the results of median and mode. 


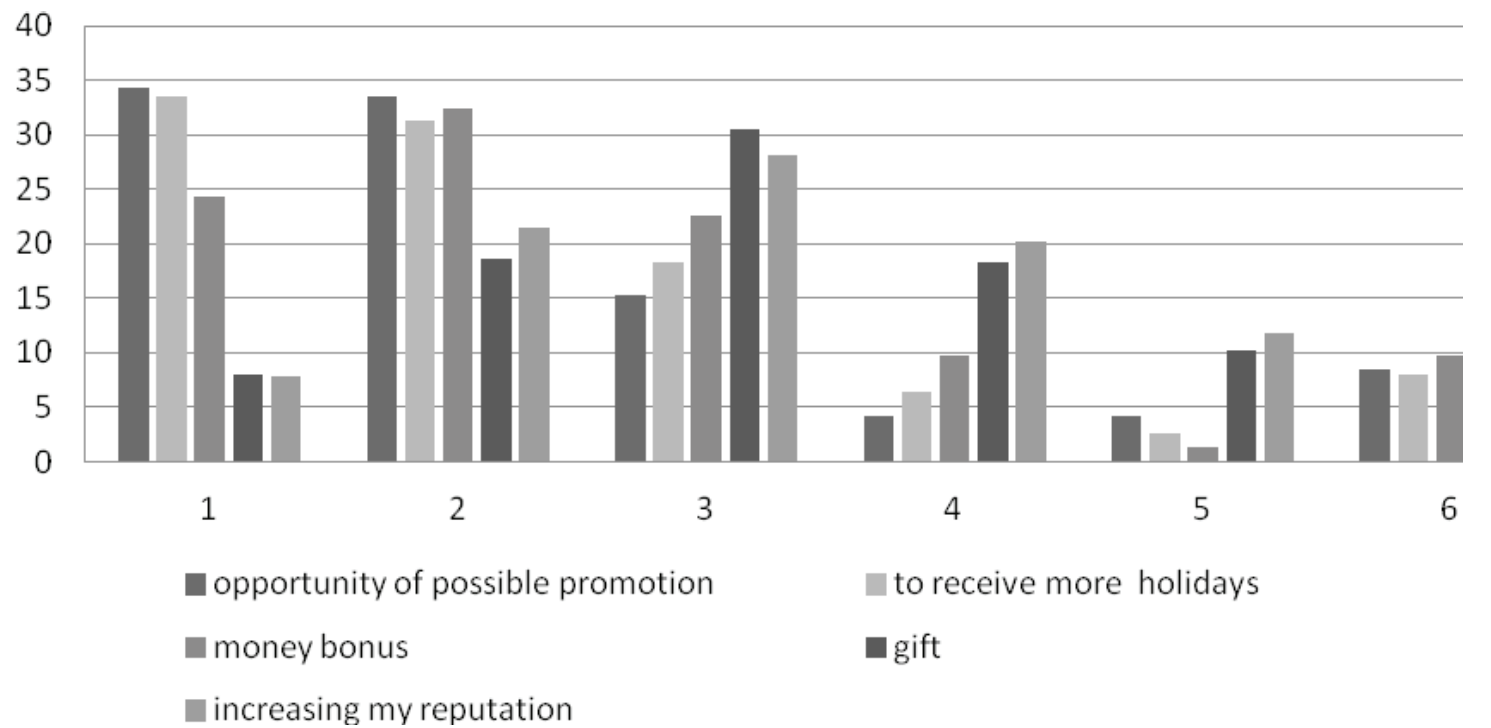

Figure 3. Distribution of responses on question "What is the motivation to encourage somebody to apply for an open position in my company?" (in \%)

Source: Tom Sander conducted survey in 2016, $n=241$; Evaluation scale 1 - full agreement; 6 - full disagreement

Table 3. Main statistical indicators of central tendency on possible disadvantages to recommend an individual to the employer

\begin{tabular}{|l|l|l|l|}
\hline & $\begin{array}{c}\text { Competition }- \text { a new employee } \\
\text { could get my position }\end{array}$ & $\begin{array}{c}\text { Business and private life } \\
\text { should be separated }\end{array}$ & $\begin{array}{c}\text { I would feel responsible if the new } \\
\text { employee would not perform well }\end{array}$ \\
\hline Mean & 3,33 & 2,53 & 1,79 \\
\hline Median & 4 & 3 & 2 \\
\hline Mode & 3 & 2 & 1 \\
\hline
\end{tabular}

Source: Tom Sander conducted survey in 2016, $n=240$; Evaluation scale 1 - full agreement; 6 - full disagreement

The frequency and details are presented in diagram four. There is clearly visible that the feeling of responsibility has a strong tendency to full agreement. That is the major issue of the respondents not to recommend somebody to the employer. The main share of responses by the respondents was on the three last stages has the dispute of a new position.

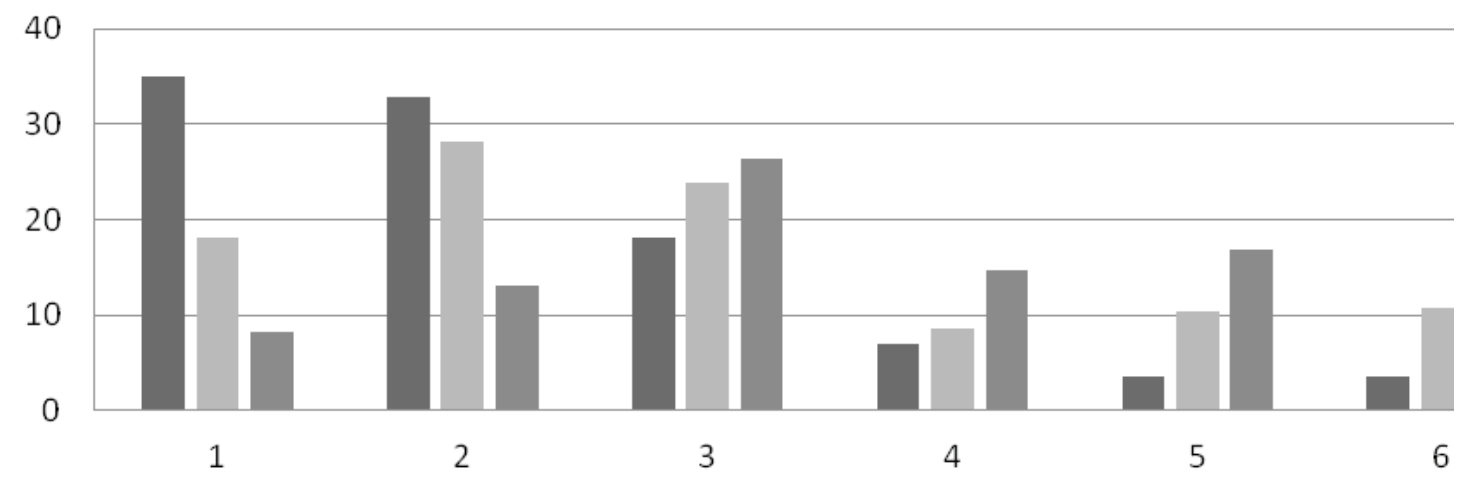

I would feel responsible if the new employee would not perform well

Business and private life should be seperated

- Competition - a new employee could get my position

Figure 4. Distribution of responses on question "Why would you not recommend an individual to your employer?" (in \%)

Source: Tom Sander conducted survey in 2016, $n=240$; Evaluation scale 1 - full agreement; 6 - full disagreement 
The respondents evaluated possible advantages of "employee recruits employees". They rate all statements with median of three and mode of three. The advantages if compared with the disadvantages describe differences. The tendency of the advantages is more normal distributed than the disadvantages. It is not possible to describe a clear tendency as presented for the disadvantages. The full agreement to the advantages is not as strong as for the disadvantages. That means individuals do not evaluate the disadvantages similar as advantages. Employees do not rate the advantages as good as the disadvantages. That is a negative outcome for the tool "employees recruit employees". The indicators of central tendency or location (arithmetic mean, median and mode) are very alike for all analysed aspects.

Table 4. Main statistical indicators of central tendency of advantages for companies to use „employee recruits employees“

\begin{tabular}{|c|c|c|c|}
\hline & $\begin{array}{c}\text { The team spirit will be increased } \\
\text { because employees know each other } \\
\text { privately. }\end{array}$ & $\begin{array}{c}\text { The cost efficiency is more } \\
\text { beneficial as for traditional } \\
\text { recruiting processes }\end{array}$ & $\begin{array}{c}\text { Only suitable candidates } \\
\text { would be employed }\end{array}$ \\
\hline Mean & 2,46 & 2,83 & 2,78 \\
\hline Median & 3 & 3 & 3 \\
\hline Mode & 3 & 3 & 3 \\
\hline
\end{tabular}

Source: Tom Sander conducted survey in 2016, $n=238$; Evaluation scale 1 - full agreement; 6 - full disagreement

The Figure 4 and 5 of advantages and disadvantages compared with each other provides a clear picture that the results of the disadvantages have a higher tendency to full agreement than the advantages. There is the distribution more next to a normal distribution for the frequency of the advantages than the frequency of disadvantages. A clear tendency as for disadvantages is not given for the advantages. The evaluation of respondents regarding "employee recruits employees" advantages and disadvantages is different.

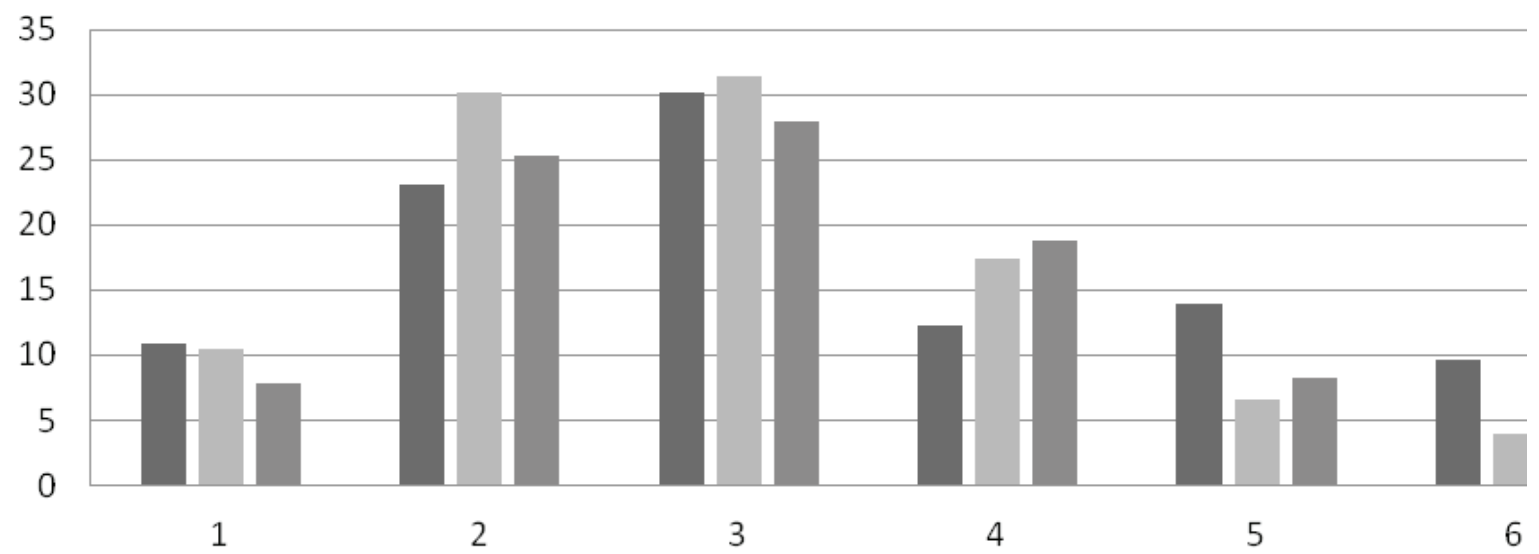

- Only suitable candidates would be employed

- The team spirit will be increased because employees know each other privately.

The cost efficency is more benefical as for traditional recruiting processes

Figure 5. Distribution of responses on statement "I could imagine "employee recruits employee" in my company, because..." (in \%)

Source: Tom Sander conducted survey in 2016, $n=238$; Evaluation scale 1 - full agreement; 6 - full disagreement

The analysis of the data presents significant results in the difference between male and female. The data is tested with a t-test and relevant results are presented in Table 5. 
Table 5. Results of t-test to investigate significance of differences between male and female evaluations

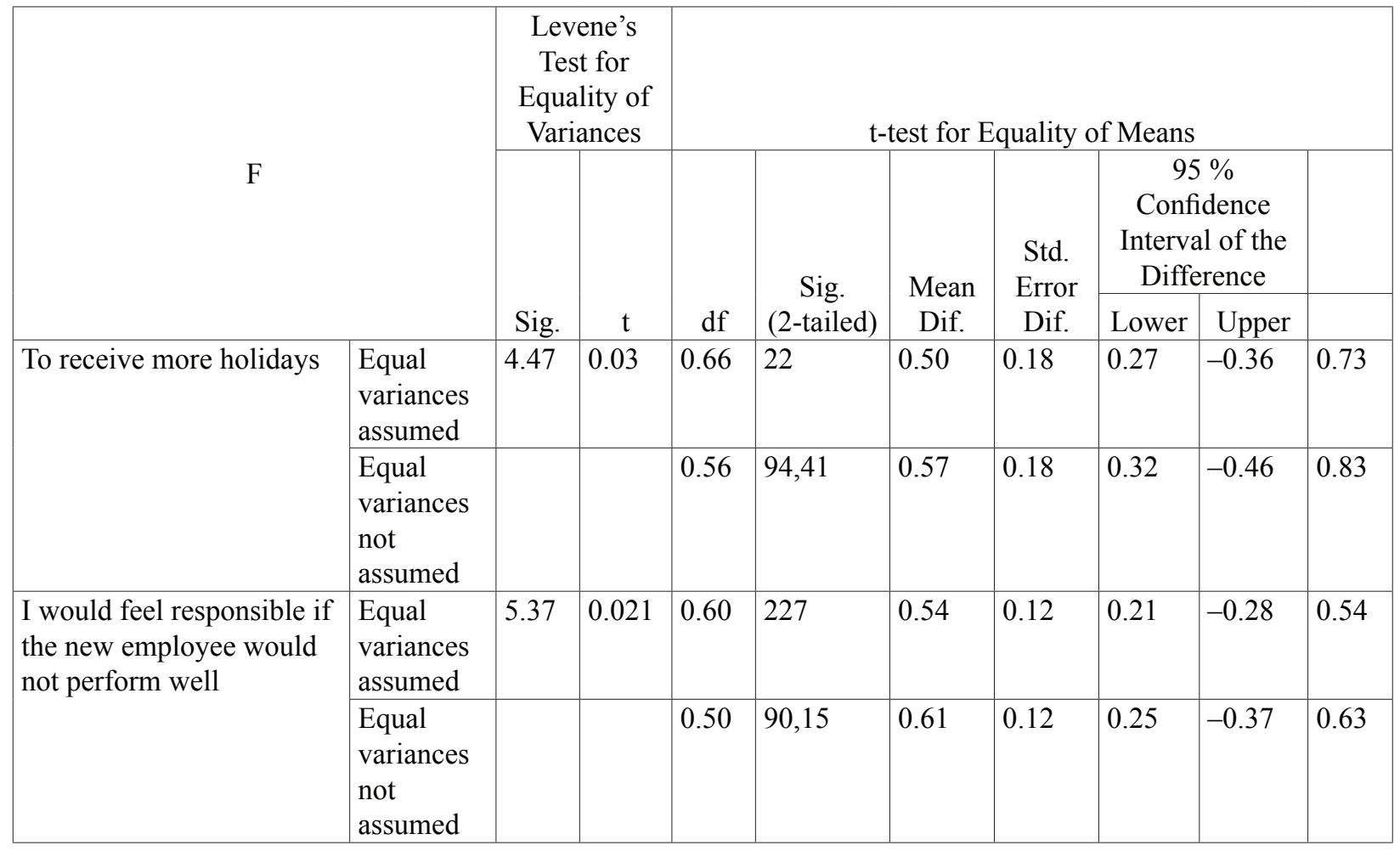

Source: Tom Sander conducted survey in 2016, $n=243$

The bonus to receive more holidays motivates men and woman in different ways. That is the only bonus with significant differences. The other significant difference between men and woman is the disadvantage "I would feel responsible if the new employee would not perform well”.

\section{Conclusions}

The different motivators have a different level of impact on the motivation to recommend somebody to employer. The motivators are not the critical issue to recommend somebody, more important is the social network. People would prefer to use their friend or colleagues network to recommend somebody. That means the dense of the network and history of the relationship is not a reason to recommend somebody. The recommendation does not depend only on the motivators the kind of social network is an important asset. Individuals reason to recommend somebody depends on the social network. The assumption that the family is the mainly mentioned social network to recommend somebody is not confirmed. This can be in relation with the disadvantages that individuals would separate private and business issues. The apparentness to recommend family member can be a reason that individuals avoid to recommend family members. The knowledge about the results at work is a reason that former colleagues are highly rated.

The dense of the social network is not essential to recommend somebody. That is of interest for the social capital theory. The assumption is that the structure and dense is important for the transfer of information in social networks. This is not confirmed with the result of the data. The recommendation is a powerful tool of social networks. People in social networks invest their knowledge and resources, a return of the investment can be the recommendation to an employer for example. That would be a benefit for individuals but this is not observable in the same intensity in different social network. The social capital can be exchanged with the "employee recruits employee" process. The individuals get for their investment in social networks and relationships real capital e.g. the bonus for a positive recommendation. The return of social capital is the bonus and the value of the individual to recommend somebody e.g. improving the team spirit. The negative 
social capital is anticipated. The responsibility for the recommended individual from the social network can be dangerous for the recommender. That can destroy social capital and reputation because the value of recommendations in the future decreases for example. Positive for the social capital is that the respondents agree that they are responsible for the new employee. They support the recommended new employee. That is a positive aspect of social capital in this case. Individuals need knowledge about the skills of their network to recommend somebody successfully. This is not given in all social networks and is a reason that the participants agree that former colleagues are a good social network to recommend.

The immaterial motivator has the lowest agreement rate e.g. increasing of reputation is not a good bonus in the opinion of respondents. The best bonus to motivate employees for the "employee recruit employees" process is the opportunity to be promoted or to receive more holidays. Money is on the third place maybe individuals have negative emotions or ethical concerns to receive money for the recommendation of friends. That supports the decision of employees to recommend somebody from their social network. Under consideration has to be that the respondents are from Germany. The bonus depends on the cultural background and values of the society.

The control of success and result is important for individuals. The responses to the statement regarding advantages and disadvantages of employee recruits employees provide the assumption that the control and result is very important. Employees would not recommend somebody if they expect that the individual will fail or they would expect that the new employee would be a competitor for example.

The research needs further investigation for other social networks e.g. virtual social network. The motivators can be more precise e.g. definition of the money value with concrete figures. The gender distribution bias the sample. The gender difference needs further and deeper research in future investigations.

\section{References}

Baker-Doyle, K. J. (2015). Stories in networks and networks in stories: a trimodal model for mixed-methods social network research on teachers. International Journal of Research \& Method in Education, Vol. 38, No. 1, p. $72-82$. DOI: $10.1080 / 1743727 X .2014 .911838$.

Borgatti, S. P., Ofen, B. (2010). Overview: Social Network Theory and Analysis. Social Network Theory and Educational Change. Cambridge MA: Harvard Business Review Press, p. 18-31.

Burt, R. S. (2000). The network structure of social capital. Resources of Organisation Behaviour, Vol. 22, p. 345-423.

Castells, M., Tubella, I., Sancho, T., Diaz de Isla, M. I., Wellman, B. (2004). Social structure, cultural identity, and personal autonomy in the practice of the internet: the network society in Catalonia. Network society, a cross cultural perspective. Cheltenham: Castells, Manuel, p. 233-248.

Chang, P. F., Choi, Y. H., Bazarova, N. N., Löckenhoff, C. E. (2015). Age Differences in Online Social Networking: Extending Socioemotional Selectivity Theory to Social Network Sites. Journal of Broadcasting \& Electronic Media, Vol. 59, No. 2, p. 221-239. DOI: 10.1080/08838151.2015.1029126.

Granovetter, M. S. (1973). The strength of weak ties. American Journal of Sociology, Vol. 78, No. 6, p. 1360-1380.

Granovetter, M. S. (1995). Getting a job. $2^{\text {nd }}$ ed. Chicago: The University of Chicago Press.

Gray, M., Kurihara, T., Hommen, L., Feldman, L. (2007). Networks of exclusion: job segmentation and social networks in the knowledge economy. Equal Opportunities International, Vol. 26, No. 2, p. 144-161.

Han. J., Han, J. (2009). Network-based recruiting and applicant attraction in China: insights from both organizational and individual perspectives. International Journal of Human Resource Management, Vol. 20, No. 11, p. 2228 2249.

Helliwell, J. F., Putnam, R. D. (1999). Economic growth and social capital in Italy. Social Capital: A Multifaceted Perspective. Washington D.C., p. 253-268.

Houghton, D. J, Joinson, A. N. (2010). Privacy, Social Network Sites, and Social Relations. Journal of Technology in Human Services, Vol. 28, No. 1-2, p. 74-94. DOI:10.1080/15228831003770775.

Lado, A. A., Wilson, M. C. (2015). Human Resource Systems and Sustained Competitive Advantage: A CompetencyBased Perspective. Academic Management Review, Vol. 19, No. 4, p. 699-727.

Mayer, A. (2012). The structure of social networks and labour market success. Applied Economics Letters, Vol. 19, No. 13, p. 1271-1274. DOI: 10.1080/13504851.2011.619484.

McDonald, N. L., Ao, D. (2009). Networks of Opportunity: Gender, Race, and Job Leads. Social Problems, Vol. 56, No. 3, p. 385-402. 
McDonald, S. (2011). What's in the 'old boys' network? Accessing social capital in gendered and racialized networks. Social Networks, Vol. 33, No. 4, p. 317-330.

Phillipsm, J. M., Gully, S. M. (2015). Multilevel and Strategic Recruiting : Where Have We Been, Where Can We Go From Here? Journal of Management, Vol. 41, No. 5, p. 1416-1445.

Portes, A. (2000). The two meanings of social capital. Sociologic Forum, Vol. 15, No. 1, p. 1-12.

Potkány, M., Hajduková, A. (2015). Social networks and their importance in job searching of college students. Business Theory and Practice, Vol. 16, No. 1, p. 75-83.

Racz, S. (2000). Finding the right talent through sourcing and recruiting, Modern HR in Cloud, Oracle. Available in: http://www.oracle.com/us/products/applications/human-capital-management/talent-mgmt-rec-best-practices-2157035.pdf [acessed 27.07.2016].

Roberts, G., Sambrook, S. (2014). Social networking and HRD. Human Resource Development International, Vol. 17, No. 5, p. 577-587. DOI:10.1080/13678868.2014.969504.

Sarabia, I., Estévez, A. (2016) Sexualized behaviours on Facebook. Computers in Human Behavior, Vol. 61, No. 1, p. 219-226.

Sauer, N. C., Kauffeld, S. (2013). Meetings as Networks: Applying Social Network Analysis to Team Interaction. Communication Methods and Measures, Vol. 7, No. 1, p. 26-47. DOI: 10.1080/19312458.2012.760729.

Sorokowski, P., Sorokowska, A., Frackowiak, T., Karwowski, M., Rusicka, I., Oleszkiewicz, A. (2016). Sex differences in online selfie posting behaviors predict histrionic personality scores among men but not women. Computers in Human Behavior, Vol. 59, p. 368-373.

\section{SOCIALINIAI TINKLAI KAIP MOTYVACIJA DARBUOTOJAMS IEŠKOTI NAUJŲ DARBUOTOJŲ}

\section{TOM SANDER, BIRUTA SLOKA}

Ludwigshafeno universitetas (Vokietija), Latvijos universitetas (Latvija)

\section{Santrauka}

Socialiniai tinklai yra svarbūs žmogiškujju išteklių vadyboje identifikuojant darbuotojus. Galimų darbuotojų skaičius specifinei darbo vietai mažèja, todèl organizacijos ieško naujų darbuotojų paieškos būdų. Šis tyrimas ịvertina ịvairių socialinių tinklų vertę - jų privalumus ir trūkumus. „Darbuotojas įdarbina darbuotojus“ yra puikus potencialių darbuotojų paieškos būdas. Šiame straipsnyje siekiama išanalizuoti individų motyvus ir priežastis, kodèl jie rekomenduoja kitą asmenį darbdaviui. Tyrimas atliktas taikant mokslinių straipsnių analizès ir respondentų apklausos (apklaustas 251 respondentas) metodus. Nematerialios priežastys mažiausiai motyvavo respondentus, pvz., įmonès reputacijos pagerinimas, jų teigimu, neatrodè vertingas. Geriausias būdas motyvuoti darbuotojus įdarbinti naujus darbuotojus buvo galimybė užimti aukštesnes pareigas arba gauti papildomų atostogų. Pinigai - trečia pagal reikšmingumą skatinimo priemonè, nes individai kartais jaučiasi besielgiantys neetiškai, kai gauna pinigus už tai, kad pasiūlè savo draugu i darbo vietą. Verta paminèti, kad šio tyrimo respondentai yra iš Vokietijos, o teigiamai vertinamos premijos priklauso nuo kultūros ir visuomenès puoselejjamų vertybių. Gauti tyrimo atsakymai apie „darbuotojus, kurie samdo darbuotojus" sistemos pliusus ir minusus leidžia teigti, kad galimybė kontroliuoti procesą ir rezultatą respondentams yra labai svarbi. Darbuotojai nerekomenduotų asmens, jeigu manytų, kad šis nesugebès atlikti darbo ar galètų tapti konkurentu.

PAGRINDINIAI ŽODŽIAI: socialinis tinklas, socialinis kapitalas, darbuotojas samdo darbuotojus, žmogiškuju ištekliu valdymas.

JEL KLASIFIKACIJA: L14; E24; O15. 